\title{
Development of Urban Green Open Space (UGOS) Based On Its Function, Model and Location In Kupang City, Indonesia
}

\author{
1,Irene Lestari, 2,Bagyo Yanuwiadi 3,Soemarno \\ 1,Environmental Resource Management Master Program, Graduate School, University of Brawijaya, Indonesia. \\ 2,Biology Department, Fac. of Mathematics and Natural Sciences, University of Brawijaya, Indonesia. \\ 3,Soil Science Department, Fac. of Agriculture, University of Brawijaya, Indonesia.
}

\begin{abstract}
Urban Green Open Space (UGOS) in Kupang city is absolutely needed because it produces various environmental benefits for urban communities. However, the fact is that changing on UGOS function shift to physical buildings massively which is not appropriate with any principles of sustainable development. This issue produces instabilities on the urban ecosystem. Specifically, this research is undertaken in Kupang, the capital city of province of Nusa Tenggara Timur, Indonesia. The main reason using Kupang is the center of province government and one of developing cities in Indonesia has changed pattern of land use reducing UGOS. According to that reasons, the research purpose is to analyze the priority of UGOS development in Kupang based on its functions (ecology, social, economic, and esthetics), design or model (area, node and path), and location. Research methode generates quantitative approach applying Analytical Hierarchy Process (AHP) method. It is one of method to assist constructing priority based on multi creteria from structural and logical processes. Research findings suggest that the priority of UGOS at Kupang city is the Ecological UGOS with path model and it needs to be developed in the Path No.5 of the Frans Seda street, Oebobo district, Kupang Nusa Tenggara Timur (NTT).
\end{abstract}

Keywords: - Analytical Hierarchy Process (AHP), Urban Green Open Space (UGOS).

\section{INTRODUCTION}

Urban Green Open Space (UGOS) is a term that has been acknowledged for long within environmental world, planning, architecture, agriculture, forest, and various scientific disciplines (Irwan, 2005). The Manual of Green Open Space Development in Urban areas has determined that quality of life in urban areas, including land, water, and atmospheric resources, can only be improved with efforts to maintain and to develop any green open spaces. The UGOS is useful in improving qualities of urban environmental, such as modifying the esthetical aspects, controlling soil erosion and surfeca runoff, reducing air pollution, reducing noises, controlling wastewater and reducing any malodorous in urban environment (The Decree of The Indonesia Public Work Ministry, 2008).

The presence of UGOS as the specific zone to support urban environment quality is absolutely needed because it has great benefits for the urban human being and for the quality urban environment (Khalid, 2008). However, it is ironic to find that UGOS has been replaced with various buildings. Despite the importance of these buildings on economic, education, health and industry sectors, there are great negative impacts on quality of urban environment (Wahyudi, 2009). Degradation of the UGOS indicates that a main problem experienced by the urban areas is not merely a crisis of urban planning processes, but also crisis of the planning objects. For example, the global climate change has increased earth temperature and it must be worsened by the reduction of UGOS as the absorber of atmospheric CO2. Environmental of comfort as a part of human beeing is not anymore felt by urban community (Dahlan, 2004). The conversion of UGOS is continually happened causing more reduction of UGOS. It is said that urban-land conversion is not compared proportionally to the improvement or deployment of the UGOS. It does not reflect the development sustainable principle where the development should be carried out to meet demand of recent generation without decreasing any abilities to meet demand of next generations (Purnomohadi, 2006).

Kupang City is the capital city of Nusa Tenggara Timur (NTT) Province. It is also one developing city with a high rate of land conversion in recent years. This land conversion is narrowing UGOS which is important to meet demand of environmental services (Development Plan of Kupang City, 2010). The presence of UGOS is reduced in quality and quantity, and this reduction is made evident with the change of urban landuse. This changing pattern is oriented toward physical development, especially for the center of trade and public services which are recently very popular businesses in Kupang City (Developent Plan of Kupang City, 2010). The absence of integrative planning with detail review only ensures the degradation of urban environmental quality. The optimum benefit of such planning must be understood, and therefore, it needs a 
review about the priority of UGOS development based on its function, model, and location by considering characteristics of Kupang city as the center of governmental activities.

There are five locations selected to represent the presence, condition and character of UGOS in Kupang city. The modeling of UGOS includes five locations of the area-model, five locations of the node-model, and five locations of the path-model. Besides the location, the priority of UGOS development in Kupang also considers several functions (ecology, social, economic and esthetical functions) and models (region, node, and path). The priority is determined using Analytical Hierarchy Process (AHP). Because of its multi-criteria, AHP is often used for the setting of priority. AHP is also used because it is a structured process based on logic (Wayan \& Munadi, 2007).

Objective of research is to analyze the priority of UGOS development in Kupang City based on its functions (ecology, social, economic, esthetical function), models (region, node and path), and its location.

\section{RESEARCH METHOD}

Field research is carried out from August 2012 to December 2012. The location is the Kupang city, Nusa Tenggara Timur, Indonesia. Purposive sampling is used in selecting respondent, the sample is taken intentionally. The author determines the sample because of certain reason or its alignment with research objective. In other word, sample is not selected randomly, or it is self-determined by the author. Through purposive sampling, it is expected the sample criteria will be matched with research (Haq, 2011). Respondent of this research involves many experts such as those from the government office of Kupang City, communityleader, TVRI of Kupang, academician, researcher of Indonesia Science Institute, and consultant agency, who each has competencies in determining criteria of the decision making in UGOS development.

Data analysis method is analytical hierarchy process (AHP). It is a method to allow the setting of the priority from several choices based on some criteria where AHP is based on structure and logic using quantitative formula. Data are analyzed by using the comparison paired method, i.e between criteria, between sub-criteria, and consistency test. Calculation of the consistency index used these following formula (Saaty, 2002):

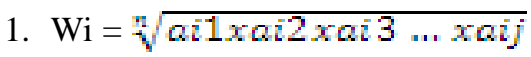

$\mathrm{Wi}=$ Principal eigenvector components of each line

2. $\mathrm{Xi}=\frac{W / 2}{\Sigma W /}$

$\mathrm{Xi}=$ Eigenvektor (local priorities)

3. $\lambda \max =\Sigma \mathrm{aij} \mathrm{Xj}$

$\lambda \max =$ Max Eigenvalue

4. IK $=(\lambda \operatorname{makx}-\mathrm{n}) /(\mathrm{n}-1)$, syarat IK $\leq 0,1$

$\mathrm{IK}=$ Consistency index $(\mathrm{CI})$

The criteria used are :

1. The UGOS functions: ecological, social, economical, and aesthetical functions

2. The UGOS models: Area, Node, Path Model

3. The UGOS location

There are five locations represent the presence, condition, and character of UGOS in Kupang city, which involves:

a. Five locations of the UGOS Area Model

1. Location 1 is the Sasando Park, it is located in the Kelapa Lima Sub-District, Kelapa Lima Village

2. Location 2 is the Mongonsidi area, it is located in the Kelapa Lima Sub-District, Kelapa Lima Village

3. Location 3 is the DTKP green open space based on the local government regulation No. $07 / 2000$, it is located in the Kelapa Lima Sub-District, Kelapa Lima Village

4. Location 4 is the Nostalgia Park, it is located in the Oebobo Sub-District, Fatululi Village

5. Location 5 is the Jogging Track Area, it is located in the Oebobo Sub-District, Fatululi Village.

b. Five locations of the UGOS Node Model

1. Location 1 is the Nefonaek Park, it is located in the Old City Sub-District, Nefonaek Village

2. Location 2 is the Mr. Erik house, it is located in the Old City Sub-District, Nefonaek Village

3. Location 3 is the Mr. Andik house, it is located in Kelapa Lima Sub-District, Kelapa Lima Village

4. Location 4 is the Oebobo Field, it is located in Oebobo Sub-District, Oebobo Village

5. Location 5 is the Nefonaek Field, it is located in the Old City Sub-District, Nefonaek Village. 
c. Five locations of the UGOS Path Model

1. Location 1 is the Veteran Path, it is located in the Kelapa Lima Sub-District, Kelapa Lima Village

2. Location 2 is the Inaboi Path, it is located in the Kelapa Lima Sub-District, Kelapa Lima Village

3. Location 3 is the Sk Lerik Path, it is located in the Kelapa Lima Sub-District, Kelapa Lima Village

4. Location 4 is the Eltari Path, it is located in the Oebobo Sub-District, Fatululi Village

5. Location 5 is the Frans Seda Path, it is located in the Oebobo Sub-District, Fatululi Village.

\section{RESULT AND DISCUSSION}

The development of urban GOS may give optimum benefits, and therefore, it needs a review about the priority of GOS development based on function, model and location of GOS to be matched with region characteristic (Irene et al., 2013). The three AHP stages in the priorities setting are : (1) Problem Decomposition; (2) Assessment to compare components of research problems; (3) Synthesis of Priorities.

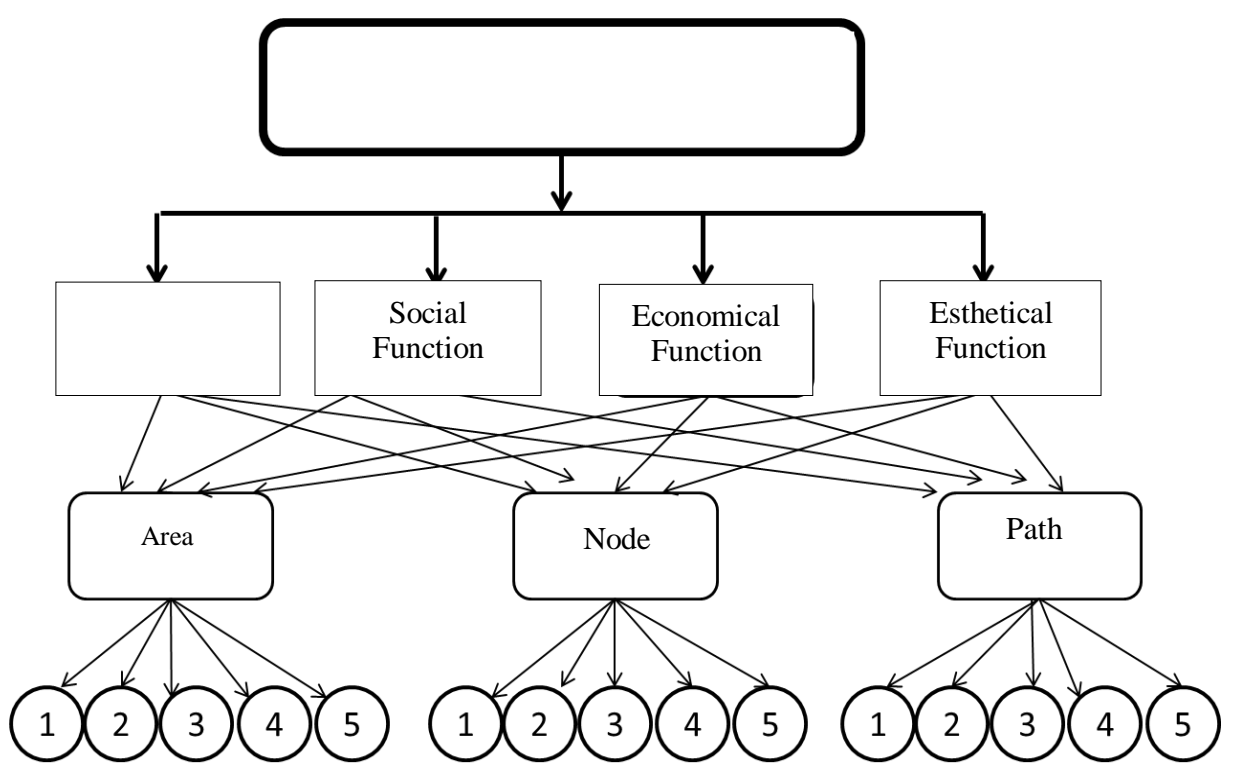

Fig 1. AHP hierarchy structure for the priority of GOS development In Kupang City, Indonesia

Table 1. Fundamental Scale of AHP (Saaty, 2002)

\begin{tabular}{lll}
\hline $\begin{array}{l}\text { Intensity of } \\
\text { Importance }\end{array}$ & Definition & Explanation \\
\hline 1 & Equally Important & $\begin{array}{l}\text { Two elements have similar influence } \\
\text { on goal. }\end{array}$ \\
\hline 3 & $\begin{array}{l}\text { Slightly more important than most } \\
\text { other elements }\end{array}$ & $\begin{array}{l}\text { Experience and judgment may give a } \\
\text { slight support to one element than } \\
\text { others. }\end{array}$ \\
\hline 7 & Clearly more important & $\begin{array}{l}\text { Experience and judgment are clearly } \\
\text { giving stronger support to one } \\
\text { element than others. }\end{array}$ \\
\hline 9 & Very obvious More Important & $\begin{array}{l}\text { One element is strongly supported } \\
\text { and dominantly seen in the practice }\end{array}$ \\
\hline $2,4,6,8$ & Absolutely more important & $\begin{array}{l}\text { The evidence supporting one element } \\
\text { to others has very strong } \\
\text { identification rate. }\end{array}$ \\
\hline Reversed & $\begin{array}{l}\text { The midpoint between two adjacent } \\
\text { decision values }\end{array}$ & $\begin{array}{l}\text { This value is given if there is two } \\
\text { compromises between two choices. }\end{array}$ \\
\hline $\begin{array}{l}\text { If activity has a higher value than } \mathrm{j} \\
\text { when compared with } \mathrm{i}\end{array}$ & \begin{tabular}{l} 
- $\mathrm{j}$ has the reversed value \\
\hline
\end{tabular}
\end{tabular}

AHP is divided into three (3) stages of analysis, which are (1) the analysis of determining the determinant factor criteria value, (2) the analysis of determining the respondent weight, and (3) the analysis of determining the selected priority (Handfield, et al., 2002). 


\subsection{Criteria Value of Determinant Criteria (GOS Function, Model, Location)}

During the implementation of the determination of the determinant factor criteria value, questionnaire is used and distributed to respondent (the experts) in order to obtain the value of each determinant factor criterion which influences the setting of the priority of GOS development in Kupang downtown. The questionnaire is the device to collect primary data. The response within questionnaire will be used as a guide to develop a matched comparison matrix between criteria. Each criterion shown by respondent is subjected to the analysis of judgment and data consistency test (Hossein et al., 2012).

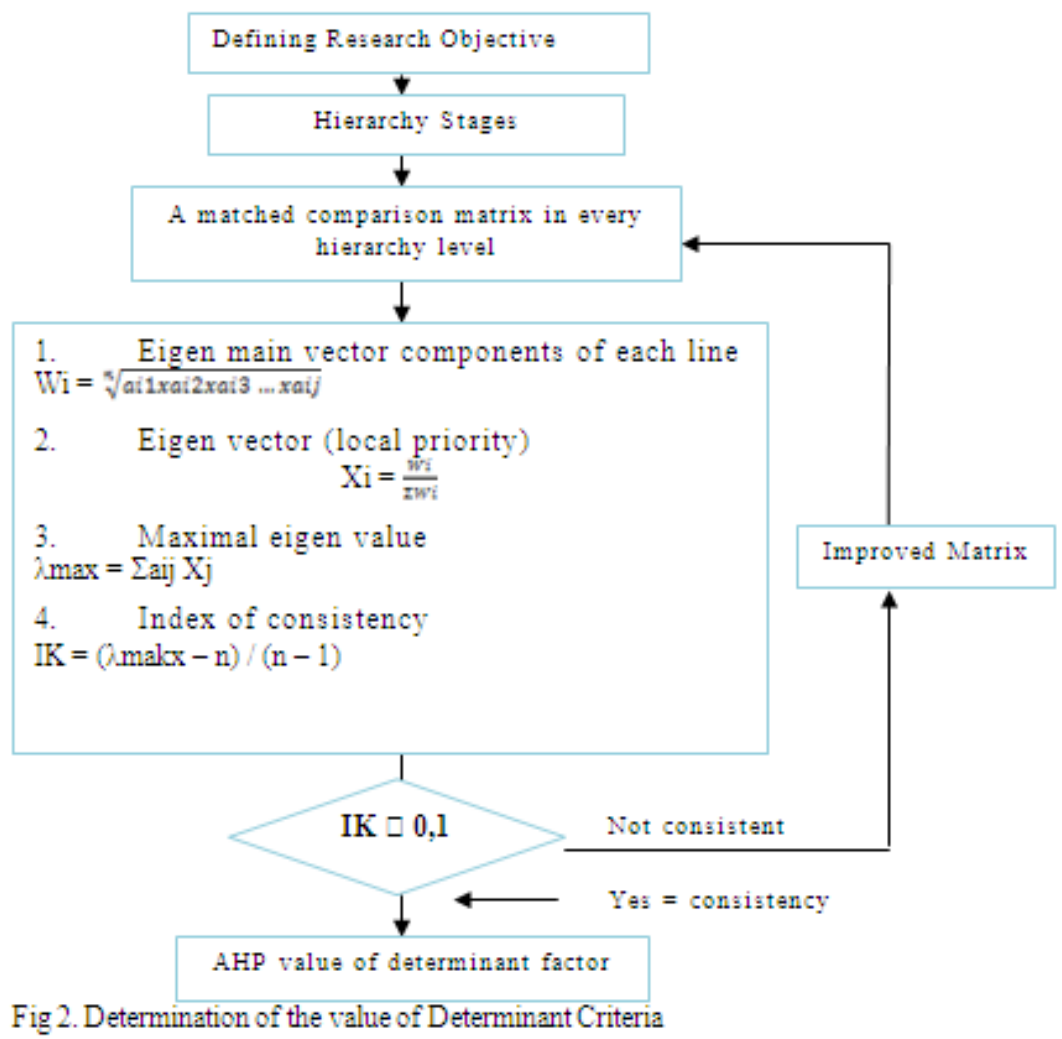

After getting calculation results of determinant criteria between each respondent, then average priority value of all respondents are determined. The priority value of average of function criteria, model and location are presented in Table 2 and Table 3.

Table 2. Average Priority Value for the UGOS Functions and UGOS Model

\begin{tabular}{llll}
\hline UGOS Functions & \multicolumn{3}{c}{ UGOS Models } \\
\hline Ecology & 0.40 & Region & 0.34 \\
Social & 0.23 & Node & 0.23 \\
Economy & 0.12 & Path & 0.43 \\
Esthetics & 0.25 & & \\
\hline
\end{tabular}

Table 3.Average Priority Value for the UGOS Locations

\begin{tabular}{llllll}
\hline \multicolumn{5}{c}{ UGOS Locations } \\
\hline Area 1 & 0.16 & Node 1 & 0.17 & Path 1 & 0.24 \\
Area 2 & 0.15 & Node 2 & 0.09 & Path 2 & 0.18 \\
Area 3 & 0.12 & Node 3 & 0.12 & Path 3 & 0.15 \\
Area 4 & 0.23 & Node 4 & 0.31 & Path 4 & 0.16 \\
Area 5 & 0.34 & Node 5 & 0.31 & Path 5 & 0.26 \\
\hline
\end{tabular}

Based on the priority value of the determinant factor (UGOS function, model, and location), then it is multiplied by the weight of each respondent to get the final result of the AHP analysis, it is the priority of UGOS. 


\subsection{Analysis of the Respondent Weight}

To determine the respondent weight, it should be understood first the contribution and experience of each respondent, either institutional or individual, in the decision making related to UGOS development in Kupang City. After the contribution and experience is understood, the weight of respondent is determined. The selected respondents are experts with adequate experiences in their professional field such that they must familiar with the priority of urban UGOS development and should have informations about the UGOS conditions in Nusa Tenggara Timur Province, especially Kupang City. Therefore, the perception of experts must be representative and accountable for its accuracy. The selected respondents have different weight depending on the influence and experience. For example, the weight of the expert from the government of Kupang City is different from the weight from community figure, academician, researcher etc. This research uses several weights of 5, 4, 3, 2 and 1 . The following is the explanation:

a) The Weight of 5: Respondents Absolutely involved in decision making processes, it means that respondent capable to give consideration "should not be", "should be", and this is the main requirement in decision making of UGOS development.

b) The Weight of 4: Respondents Highly involved in decision making processes, it means that respondent is considered very involved in decision-making of UGOS development.

c) The Weight of 3: Respondents Obviously Involved in decision making processes, it means that respondent is considered definite involved in decision making of UGOS development.

d) The Weight of 2: Respondents Involved in decision-making, it means that respondent is considered have any role in decision-making of UGOS development.

e) The Weight of 1: Respondents have a little involvement in decision making, it means that respondent is considered not influential or somewhat influential in decision making of GOS development.

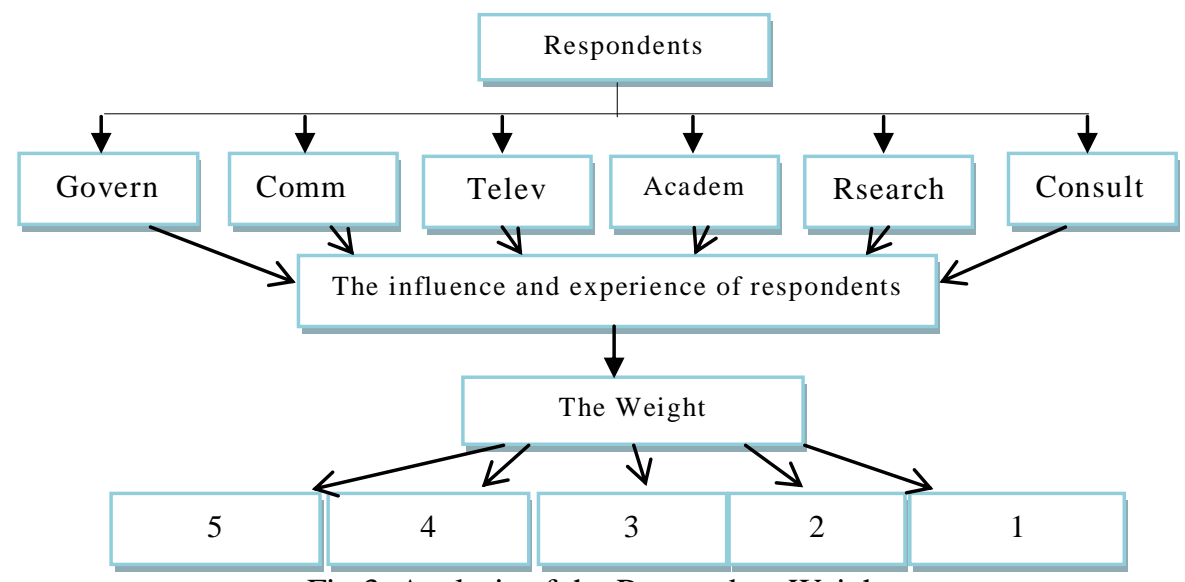

Fig 3. Analysis of the Respondent Weight

Respondents Group and the Respondent Weight:

The weight of respondent from Governmental offices

1. Head of Development Planning Office $: 5$

2. Head of Urban and Regional Planning Office $\quad: 5$

3. Head of Division of Environmental Impact Control Office $\quad: 5$

4. Head of the Forestry Office $: 5$

5. The Governor's Secretary Office $\quad: 5$

The weight of Community Leader

6. H.Ust. Amir Kiwang $\quad: 2$

The weight of Mass Media

7. The Head of the Kupang Television $\quad: 2$

The weight of Academic staffs

8. Agricultural Lecturer of the Nusa Cendana State University :4

9. Environmental Engineering Lecturer of National Institute of Technology : 3

10. Head of Urban and Regional Planning Department, the National Institute of Technology : $: 4$

The weight of Researchers

11. Environmental Researcher of the Indonesian Institute of Sciences (IIS) $: 3$

12. Urban sociology researcher of the Indonesian Institute of Sciences (IIS) $: 3$

The weight of Consultant

13. Director of Regional Planning Consultant $: 4$ 
14. The landscape architecture expert

$: 2$

15. Director of Urban Spatial planning Consultant

$: 3$

\subsection{Priority Analysis}

The average priority rate of the determinant factor criteria is timed with the average priority rate of respondent weight to obtain the score total to determine the priority of GOS development in Kupang city. The priority of UGOS development in Kupang is presented in Table 4, 5 and 6.

Table 4. The UGOS Development Priority Based on its Function

\begin{tabular}{|c|c|c|}
\hline Priority & $\begin{array}{c}\text { Urban Green Open Space } \\
\text { (UGOS) }\end{array}$ & Total Score \\
\hline I & Ecology Function & 22.00 \\
\hline II & Esthetic Function & 13.75 \\
\hline III & Social Function & 12.65 \\
\hline IV & Economic Function & 6.60 \\
\hline \multicolumn{3}{|c|}{ Table 5. The UGOS Development Priority Based on its Model } \\
\hline Priority & $\begin{array}{c}\text { Urban Green Open Space } \\
\text { (UGOS) }\end{array}$ & Total Score \\
\hline I & Path UGOS & 23.65 \\
\hline II & Region UGOS & 18.70 \\
\hline III & Node UGOS & 12.65 \\
\hline \multicolumn{3}{|c|}{ Table 6. The UGOS Development Priority Based on its Location } \\
\hline Priority & $\begin{array}{c}\text { Urban Green Open Space } \\
\text { (UGOS) }\end{array}$ & Total Score \\
\hline I & Path UGOS & 23.65 \\
\hline 1. & Path 5 & 14.30 \\
\hline 2. & Path 1 & 13.20 \\
\hline 3. & Path 2 & 9.90 \\
\hline 4. & Path 4 & 8.80 \\
\hline 5. & Path 3 & 8.25 \\
\hline II & Area UGOS & 18.70 \\
\hline 1. & Area 5 & 18.70 \\
\hline 2. & Area 4 & 12.65 \\
\hline 3. & Area 1 & 8.80 \\
\hline 4. & Area 2 & 8.25 \\
\hline 5. & Area 3 & 6.60 \\
\hline III & Node UGOS & 12.65 \\
\hline 1. & Node 5 & 17.05 \\
\hline 2. & Node 4 & 17.04 \\
\hline 3. & Node 1 & 9.35 \\
\hline 4. & Node 3 & 6.60 \\
\hline 5. & Node 2 & 4.95 \\
\hline
\end{tabular}

Based on the priority value, it can be suggested that priority of UGOS development in the Kupang city are more emphasized on the ecological functions (first priority with the highest score total of 22.00) with the model of UGOS development of road path (first priority with the highest score total of 23.65), and automatically, the location of the development is placed on the road path 5, precisely at Frans Seda Street in Oebobo District, Fatululi Village, with the highest score total of 14.30 compared to other road paths.

\section{CONCLUSION AND SUGGESTION}

The ideal Urban Green Open Space (UGOS) should produce benefits in term of ecology, social, esthetic and economic. Taking the principle into account, to provide optimum benefit, the review on the priority of UGOS development based on function, model and location in match with the regional characteristic of Kupang city is needed. Based on Analytical Hierarchy Process (AHP), it is suggested that the UGOS development priority in Kupang city, based on its function, is concerned more on the ecological functions. The model is related to road path, and the location of UGOS development remains in road path no.5, at the Frans Seda Street in Oebobo District, Falutuli Village, Kupang City. Recalling that the research is limited on the 
determination of UGOS development priority based on function, model, and location of development, it is then expected that further research is examining the factors of selecting and determining local vegetation on UGOS in Kupang city by considering the local characteristics. This further research may be important to understand the different characteristic between location and its function. Deployment of the UGOS should be not only reviewed from the land area and the quantity of vegetation, but also understood based on the characteristics and function of these vegetation, because every species of vegetation in every character of region may have different function.

\section{REFERENCES}

[1] D. Irwan, Challenges in Environmental and Urban Forest Landscapes (Jakarta, Indonesia : Bumi Aksara Publisher, 2005).

[2] D. Irwan, Principles of Ecosystem-ecology, Environment and the Conservation (Jakarta, Indonesia : Bumi Aksara Publisher, 2007).

[3] Wahyudi, Allocation of the Urban GOS Availability, Graduate Program., University of Diponegoro, Semarang, Indonesia, 2009.

[4] Dahlan, Developing the garden city (Bogor, Indonesia : IPB Press, 2004).

[5] Purnomohadi, Green open space as the main element in the Urban Planning (Jakarta, Indonesia : Direktorat Jenderal Penataan Ruang Kementrian Pekerjaan Umum, 2006).

[6] L. Irene, Yanuwiady, and Soemarno, Suitability Analysis of Green Open Space (GOS) Model Based On Area Characteristics in Kupang City, Indonesia, The International Journal of Engineering and Science (THE IJES), 2(6), 2013, 81-91.

[7] M. Albayrakoglu, Justification of New Manufacturing Technology: A Strategic Approach Using the Analytical Hierarchy Process, Journal of Production and Inventory Management, 4, 1996, 71-80.

[8] T. Baycan, and P. Nijkamp, Planning and Management of Urban Green Spaces in Europe: Comparative analysis, Journal of Urban Planning and Development, 135, 2009, 1-12.

[9] R. Handfield, Walton, and R. Sroufe, Applying Environmental Criteria to Supplier Assessment : A study in the application of the Analytical Hierarchy Process, Journal of Operational Research, 141, 2002, 7082.

[10] A. Haq, Urban Green Spaces and An Integrative Approach to Sustainable Environment, Journal of Environmental Protection, 2, 2011, 601-611.

[11] P. Hossein, A. Seyed, and F. Yadolahi, Ranking and Investigation of Voice of Customer index by Applying AHP method in local Management of Tehran Metropolis, Journal of Management and Sustainability, 2, 2012, 1 - 15.

[12] A. Khalid, Towards a sustainable neighborhood the role of open spaces, Journal of Architectural Research, 2, 2008, $30-55$.

[13] R. Ramanathan, A Note on The Use of The Analytic Hierarchy Process For Environmental Impact Assessment, Journal of Environmental Management, 63, 2001. 27-35.

[14] Saaty, and T. L. Saaty, Decision Making in Complex Environments : The Analytic Network Process (ANP) for Dependence and Feedback (U.S.A : Pittsburgh Publications, 2002).

[15] Saaty, T. L, Fundamentals of Decision Making and Priority Theory with the AHP (U.S.A : Pittsburgh Publications, 2004). 